\title{
Strategic embarrassment and face threatening in business interactions
}

\author{
Wei-Lin Melody Chang and Michael Haugh* \\ (School of Languages and Linguistics, Griffith University)
}

\begin{abstract}
:
Face threats are generally studied as either something to be avoided or reduced in politeness research, or as deliberate forms of aggression in impoliteness research. The notion of face threat itself, however, has remained largely dependent on the intuitive notion of threatening. In Face Constituting Theory (Arundale, Robert, 2010. Constituting face in conversation: face, facework and interactional achievement. Journal of Pragmatics 42, 2078-2105), an approach to theorising face threats is posited that goes beyond such pre-theoretical notions. The advantages of employing such an analytical framework is that interactional practices which are open to evaluation as face threatening can be explicated in a manner that is grounded in the perspective of the participants, yet the range of practices examined can be expanded beyond that encompassed by folk or first-order conceptualisations of face. In this paper examples of one such practice, namely, strategic embarrassment, where the speaker attempts to embarrass the addressee into doing what he or she wants by topicalising unmet expectations and thereby implying a mild reproach or complaint, is examined in the context of business interactions in Taiwan. The way in which this action is interactionally achieved coordinate with constituting evaluations of face threat is outlined before considering the implications of this analysis for politeness and impoliteness research more broadly.
\end{abstract}

\section{Keywords:}

face, embarrassment, interactional achievement, relationship, Taiwanese, (Mandarin) Chinese

\section{Bio-notes:}

Wei-Lin Melody Chang is a PhD student in the School of Languages and Linguistics at Griffith University, Brisbane, Australia. Her research interests include pragmatics, intercultural communication and Chinese linguistics. Her publications include 'Evaluations of im/politeness of an intercultural apology' (forthcoming in Intercultural Pragmatics), and 'Face in Taiwanese business interactions: from emic concepts to emic practices' (forthcoming in Pan and Kadar, eds., Chinese Discourse in Interaction, Equinox, London).

Michael Haugh is a senior lecturer in Linguistics and International English in the School of Languages and Linguistics at Griffith University, Brisbane, Australia. His areas of research interest include face, im/politeness, humour, intention and implicature, drawing from both interactional and discursive perspectives. He has edited a number of journal special issues, including "Intention in pragmatics" for Intercultural Pragmatics (2008, Mouton de Gruyter), "Conceptualisations of communication" for Australian Journal of Linguistics (2009, Routledge), and "Face in interaction" for Journal of Pragmatics (2010, Elsevier), as well as co-editing Face, Communication and Social Interaction (2009, Equinox) and Situated Politeness (2011, Continuum). 


\section{Strategic embarrassment and face threatening in business interactions}

\section{Introduction}

The concept of face threat has become firmly embedded in pragmatics since its introduction in Goffman's $(1955,1967)$ seminal work on face. Much of the work that has been subsequently undertaken over the past four decades in regards to face threats has focused on understanding how participants avoid or reduce face threats in interpersonal interactions, or what is commonly termed "saving face". Such work has generally come under the umbrella of politeness research. The analytical bias in the field towards studying face threat avoidance or reduction reflects Goffman's (1955, 1967) initial primary focus on face-saving, and Brown and Levinson's $(1978,1987)$ subsequent formulation of politeness as avoiding or reducing face-threatening acts. Yet despite their importance to politeness research, face threats have in themselves only recently been receiving more attention in pragmatics (Pérez de Ayala, 2001; Harris, 2001; O’Driscoll, 2007), concurrent with the rise of impoliteness research (Bousfield 2008; Bousfield and Culpeper, 2008; Bousfield and Locher, 2008; Culpeper, 1996, 2005, 2011; Kienpointner, 1997). An important insight gained such research is that no act is intrinsically face-threatening, as is often presumed to be the case in regards to Brown and Levinson's $(1978,1987)$ notion of face-threatening act (Arundale, 2006: 208-209; Fraser, 1990: 233; Fukushima, 2000: 88-89; O’Driscoll, 2007: 245; Turner, 1996: 4-5). Criticisms or insults can be face-boosting in some contexts (Daly, Holmes, Newton and Stubbe, 2004; Mills, 2005: 265), for instance, while expressions of affection (Ebert and Floyd, 2004) or compliments (SpencerOatey, 2000: 18) can be face-threatening in others. And indeed, some social actions may be evaluated as simultaneously face-threatening and face-supportive (Turner 1996). Thus, whether an action is face-threatening, and the degree of face-threat, depends on the evaluations and responses of participants in particular interactions relative to their interpersonal histories and broader sociocultural expectations (Arundale, 2010; O’Driscoll, 2007: 256; Stewart, 2008: 37), as well as their individual (or mutual) interactional goals (Spencer-Oatey, 2009). This suggests that actions/practices and evaluations of face threats should be treated as distinct analytic concerns.

Face threats have thus been deployed in two key ways in pragmatics research. In politeness research the focus has been on face threat avoidance or reduction, while impoliteness research has concentrated on deliberate or aggressive face threats, often glossed as either face attack or aggravation (Culpeper, 2005: 38; Limberg, 2009: 1376; Locher and Bousfield, 2008: 3-4; Tracy, 2008: 175-176). However, in recent work, particularly on impoliteness, there have sometimes been passing references made to practices that can be evaluated as face-threatening, yet do not necessarily fall comfortably under the umbrella of either politeness or impoliteness theories. These include what have been variously termed banter (Kienpointner, 2008: 244; Leech, 1983), jocular mockery (Haugh, 2010a), mock impoliteness (Bousfield, 2008: 136137; Culpeper, 1996: 352-353, 2011), and harmonious face threatening acts (Su and Huang, 2002). These different labels reflect the treatment of such phenomena as either primarily actions (i.e., banter, jocular mockery) or forms of im/politeness (i.e., mock impoliteness, harmonious face-threatening acts). In our view, however, the latter terms potentially confound the analysis of actions (e.g., banter, jocular mockery) with the analysis of evaluations (e.g., im/politeness, face threat). This may, in turn, prevent us from fully exploring the different ways in which face threats arise in interactions, 
particularly those practices where questions remain as to whether it is indeed possible to integrate such analyses with existing theories of politeness or impoliteness. We thus take the position that evaluations of face threat should be kept analytically distinct from explications of social actions. We also suggest that analyses of face (threats) should be kept distinct from analyses of im/politeness, at least in the first instance, due to the complex relationship between face threats and impoliteness (see also Haugh and Bargiela-Chiappini, 2010; Watts, 2003). It is then incumbent upon the analyst, in this view, to first demonstrate that the interactional achievement of a particular action is indeed evaluated (or open to evaluation) as face-threatening by participants if the analysis is to further contribute to the theorisation of face and face threats.

The paper begins by considering how face threats have been theorised thus far, and how the notion of face threat has been conceptualised in theories of politeness and impoliteness. We note that this broad notion of face threat has been deployed in describing practices whereby participants maintain or save face in the case of politeness research, or more recently in explicating practices whereby participants attack or damage face, which is commonly referred to as impoliteness. It is then argued that these practices do not exhaust the range of possible actions that can be evaluated as face-threatening, as recent work suggests that in some instances ostensibly face-threatening actions may also be understood as face-supportive or affiliative (Bousfield, 2008; Haugh, 2010a; Su and Hwang, 2002). In this paper we focus on yet another instance of a practice that can be evaluated as face-threatening yet is nevertheless treated as sociopragmatically allowable, namely, strategic embarrassment. Instances of strategic embarrassment arising in a dataset of recordings of Taiwanese business interactions through speakers topicalising unmet expectations are analysed in order to further elucidate this practice, and to explicate how it gives rise to co-ordinately constituting evaluations of face threat. While we suggest that this action is not necessarily open to being evaluated as face-supportive, it is argued that it is treated as relationship-appropriate (cf. Tracy 2008) in interactions between participants who invoke their guanxi ('connections'). In the sense that strategic embarrassment does not negatively impact upon their long-term relationship, then, it can be considered allowable, or alternatively, politic (Watts, 1989, 2003). The implications of this analysis for politeness and impoliteness research more broadly are then considered.

\section{Theorizing face threats}

The notions of face and face threat were first introduced into academic discourse in Goffman's $(1955,1967)$ seminal work. He defined face as "the positive social value a person effectively claims for himself by the line others assume he has taken during a particular contact", with a line being understood as "a pattern of verbal and nonverbal acts by which he expresses his view of the situation and through this his evaluation of the participants, especially himself" (Goffman, 1955: 213). In this way, he rooted the notion of face in the claimed self-image of individuals, consistent with the North American folk view of self (Arundale, 2009). In outlining the importance of face in interpersonal interaction, Goffman (1955) drew from English calques of Chinese emic face evaluative terms. He discussed, for example, how face can be maintained, lost, saved, and given (pp.213-215). These can be traced directly back to the Chinese expressions you/gu mianzi, diu mianzi, liu mianzi, and gei mianzi, respectively (Hu, 1944). He also introduced the notion of face threat, which, in contrast, does not have a 
clear counterpart in Chinese. In this sense, the notion of face threat is arguably theoretical in origin, differing from the notions of maintaining, losing, saving and giving face, which have pre-theoretical or folk theoretical origins in being rooted in the folk or emic metalanguage of Chinese interpersonal interaction. Yet despite first introducing the notion of face threat, Goffman (1955) did not actually clearly define what he meant by it. He distinguished between intentional, accidental (unintended), and incidental face threats (p.217), regarding intentional face threats as underpinning face aggression or attack (pp.221-222). However, he left the conceptualisation of face threat itself to rest on the intuitive notion of threaten(ing), defined as "to be likely to injure; to be a source of danger to” in the Oxford English Dictionary (2009).

This mixture of pre-theoretical (maintaining, losing, saving and giving face) and quasi-theoretical (face threatening, face aggression) notions were then employed in Goffman's (1955) theory of face-work, which has since driven the development of politeness theory, and impoliteness theory more recently. In his exposition of facework Goffman distinguished between avoidance face-work (analogous with maintaining face) and corrective face-work (analogous with saving face) (pp.217223). He also touched upon face aggression, focusing, in particular, on how individuals may threaten the face of others in order to gain face for themselves (pp.221-222). However, it was through Brown and Levinson's $(1978,1987)$ subsequent development of a theory of politeness that Goffman's initial work on face and face threats was to reach its current axiomatic status in pragmatics.

Following Goffman, Brown and Levinson (1987) drew from the pretheoretical notions of maintaining, enhancing, and losing face (p.61), in claiming that politeness arises through implicatures that minimise (analogous to maintaining face) or redress (analogous to saving face) face threats in order to maintain/save face, or to avoid loss of face (pp.59-60, 95). Unlike Goffman, however, Brown and Levinson (1987) outlined a technical definition of a face threat act (FTA), which in turn was predicated on their notions of positive and negative face, namely, the want that one's "wants be desirable to at least some others" (i.e., "approval") and the want that one's “actions be unimpeded by others” (i.e., “self-determination”) (p.62, 77). For example, they claimed that

for FTAs against positive face, the ranking involves an assessment of the amount of 'pain' given to H's face, based on the discrepancy between H's own desired self-image and that presented (blatantly or tacitly) in the FTA. (Brown and Levinson, 1987: 78)

In the case of FTAs directed towards negative face, they claimed that threats arise through impositions in regards to either "services (including the provision of time)" and "goods (including non-material goods like information, as well as the expression of regard and other face payments)" (p.77). In essence, then, according to Brown and Levinson, face threats are a consequence of behaviours in interactions that are not consistent with (or attack) the claimed interactional wants and thus public self-image of individuals. Brown and Levinson (1987: 77) also introduced a formula for estimating the degree of seriousness or weightiness of face threats $\left(\mathrm{W}_{\mathrm{x}}=\mathrm{D}(\mathrm{S}, \mathrm{H})+\right.$ $\left.\mathrm{P}(\mathrm{H}, \mathrm{S})+\mathrm{R}_{\mathrm{x}}\right)$, combining three key variables, namely, social distance (D), power $(\mathrm{P})$, and culture-specific ranking of imposition $\left(\mathrm{R}_{\mathrm{x}}\right)$, the latter involving "the degree to which they [the acts in question] are considered to interfere with an agent's wants of self-determination or approval (his negative- and positive-face wants)” (p.77). 
However, while Brown and Levinson's model has driven a large amount of subsequent research, it has been critiqued on a number of fronts. Key points of dispute include its neglect of deliberate face threats or face aggression (cf. Goffman, 1955: 221-222), which has recently become the focus of a rapidly growing body of impoliteness research (Bousfield, 2008; Culpeper, 1996, 2005, 2011; Locher and Bousfield, 2008), a definition of face overly focused on individuals wants and so arguably not cross-culturally valid (Bargiela-Chiappini, 2003; Ide, 1989; Mao, 1994; Matsumoto, 1988; Nwoye, 1992), and difficulties in estimating the variables underlying their formula for assessing the weightiness of face threats (Spencer-Oatey, 1993, 1996; Turner, 2003). It appears, then, that while Brown and Levinson (1987) attempted to carefully define the notion of face threat, their conceptualisation has since proven unduly limiting for both politeness and impoliteness researchers.

Yet despite the various criticisms of Brown and Levinson's (1987) approach to face and face threats, there have been few well-theorised alternatives proposed. Although a number of alternative frameworks have been developed, including Rapport Management Theory (Spencer-Oatey, 2000[2008], 2002, 2005), and Relational Work (Locher, 2006; Locher and Watts, 2005; Watts, 2005), what has generally been advocated since Bargiala-Chiappini's (2003) seminal discussion of face, is a return to Goffman's (1955) original rich conceptualisation of face and facework. This shift back to Goffman can be seen, for instance, in Limberg's (2009) work on verbal threats as a potential form of face aggravation. In the course of his analysis he argues that a

[verbal] threat can only turn into a face-threatening act through its use in a particular context. This involves both the intentional production of an act that causes some kind of (face) damage as well as the corresponding assessment made by the addressee based on what is considered as 'normal' and 'appropriate' in that context (Locher 2004; Locher and Watts 2005). (Limberg, 2009: 1378)

A face threat is thus defined as being realised and perceived as intentionally causing "face damage" relative to the contextualised expectations of participants. This definition largely echoes Goffman's (1955) original postulation of intended face threats, where "the offending person may appear to have acted maliciously and spitefully, with the intention of causing open insult" (p.217). However, this move inadvertently masks a shift back to an arguably under-theorized understanding of face threats, which as previously noted, ultimately rests on the intuitive notion of threatening.

While recognising the enormous contribution Goffman's $(1955,1956)$ work has made to work on face, face-work, politeness and impoliteness in pragmatics and other disciplines, then, a number of scholars have also recognised the need for further theorization (Arundale, 2009; O’Driscoll, 2009, 2011). These developments have moved in two quite different directions. On the one hand, we have O'Driscoll's (2007) approach to FTAs which seeks to expand upon Goffman's pioneering analysis. O’Driscoll (2007) defines an FTA as “any move which (regardless of the actor's intentions) is received as predicating a face inconsistent with the one presented up to that point in the ongoing situation" (p.260). He grounds the recognition of face-threats and their degree of severity in participant evaluations and responses (p.249). He rejects Brown and Levinson's (1987) approach in favour of a formula where the relative severity of an FTA is a product of two factors, Change X Salience (p.257). He 
claims that the amount of face-change depends on "how far the FTA departs from the claimed self-image" (p.257), while the degree of face-salience depends on a number of variables, including the number of witnesses (i.e., size of the audience; ratified participants vs. bystanders), nature of the occasion (i.e., routine vs. nonroutine), affective impact of the act for the addressee, and the nature of their personal relationships (i.e., power and social distance) (pp.258-259). This means that face threats are analysed in terms of their interpretation by participants and their effects rather than directly focusing on the speaker's intentions. Another important theoretical development in O'Driscoll's (2007) approach to face threats is that they are inherently situated in the ongoing historicity of both the participants and their relationships with each other, including their individual histories (cultural backgrounds and temperaments), interpersonal history (prior to encounter), the nature of occasion of which encounter is part (including their roles), and the progress of encounter up the point of the potential FTA (pp.261-262). O'Driscoll's theorisation of face threats approach thus rests on the received view of face as belonging primarily to individuals (O'Driscoll 2011), from which it follows that threats to face are directed at either the speaker's face or the hearer's face (or at the face of a third party). ${ }^{1}$

On the other hand, we have Arundale's (1999, 2006, 2010) Face Constituting Theory (FCT), which represents less of a development and more in the way of a radical re-interpretation of, and thus an alternative to Goffman's (1955) work. ${ }^{2}$ Face is re-conceptualised by Arundale as the interpretings of participants of their relationship with each other, not their perceptions of person-centred attributes. More specifically, face is defined as "participants' understandings of relational connectedness and separateness conjointly co-constituted in talk/conduct-in-interaction” (Arundale, 2010: 2078), where connectedness is understood as "meanings and actions that may be apparent as unity, interdependence, solidarity, association, congruence, and more” (Arundale, 2006: 204), and separateness is understood as "meanings and actions that may be voiced as differentiation, independence, autonomy, dissociation, divergence, and so on" (ibid.: 204). Crucially, then, in FCT the focus is on "our connection or separation" or "our face," rather than "self face” or "other face". An important consequence of this move towards a relational approach to face is that the analytical focus is shifted to the relationship between the participants. Arundale (2010) goes on to note that "in evaluating their relationship as threatened or supported, participants may also perceive their own or another's person as threatened or supported” (p.2094), and so one may evaluate one's own person or another's person as threatened or supported in that relationship. In this sense, then, FCT offers a real alternative to previous conceptualisations of face that are arguably overly focused on individuals or person-centred attributes.

The notion of face threat is also formally defined in FCT, specifically, as arising from "the process of evaluating their provisional or operative interpretings of connectedness and separateness [i.e. face] as threatening...in the relationship they are (re)creating” (Arundale, 2010: 2092). ${ }^{3}$ Evaluations of face as threatened (or

\footnotetext{
${ }^{1}$ Athough face is claimed to be shared across individuals in some societies (Haugh, 2005; Ho, 1976; Nwoye, 1992; cf. O’Driscoll 2011).

${ }^{2}$ What follows is a very brief introduction to some of the most salient aspects of FCT in regards to the analysis of strategic embarrassment. For a much more comprehensive introduction see Arundale (2010).

${ }^{3}$ An interpreting is defined as the participant's “dynamic process of forming both meanings and conversational actions". A provisional interpreting is one that is "not yet assessed in view of uptake", while an operative interpreting is one that has been "assessed in view of uptake" (Arundale, 2010: 2080).
} 
supported) are claimed to involve three types of face: (1) projected/interpreted face, namely, a participant's interpreting of the utterance or action currently in question "with regard to the extent of both connectedness with and separateness from the other person", (2) evolving face, involving a participant's interpreting of "the extent of both connectedness and separateness that characterize the relationship with this particular person, up to the current point in the interaction", and (3) contextual face, encompassing the participant's "expectation for the interpreting of connectedness with and separateness from the other person that applies in the current context, as that context has been invoked or brought into play at the present moment by the participants in the conversation” (Arundale, 2010: 2092). Evaluations of face interpretings as threatening arise when the proffered shift in face interpretings (namely, the perceived difference between the projected/interpreted face and evolving face) is not consistent with the situated shift in face interpretings (that is, the perceived difference between evolving face and contextual face). Evaluations of face interpretings as supportive, on the other hand, arise when the proffered and situated shifts in face interpretings are consistent (Arundale, 2010: 2093).

In defining evaluations of face interpretings as either being in stasis, supportive, or threatening, FCT represents a radical breakaway from previous approaches which have employed pre-theoretical notions of maintaining, saving, losing and gaining face. This is not to say that face gain or loss are not worthwhile foci of investigation, but rather that they do not necessarily constitute viable theoretical constructs. Arundale (2010) argues that

Gaining and losing face are complex emic conceptualisations (cf. Haugh, 2007:664) involving economic metaphors that equate face with money or goods. FCT could be employed in explaining change over time in face interpretings and evaluations, but here again there is no necessary link between increased connection over time and 'gain' or support, nor between increased separation and "loss’ or threat”. (Arundale, 2010: 2094)

FCT can be used to gain further insight into such emic conceptualisations, but does not seek to necessarily fully explicate them, instead treating them as first-order concepts that should inform but not overly constrain theorising of face (Chang and Haugh forthcoming; Haugh, 2009).

FCT also allows for the analysis of interactions in which evaluations of face interpretings are simultaneously threatening and supportive (Arundale, 2010: 2094; cf. Turner 1996: 4-5). Haugh (2010a), for instance, argues in his analysis of (dis)affiliative aspects of jocular mockery in (Australian) English that it can be evaluated as both face-threatening and face-supportive. Related phenomena, termed "harmonious face threatening", have also been examined in Taiwanese by $\mathrm{Su}$ and Hwang (2002). However, a more in-depth analysis of the examples Su and Hwang (2002) provide is constrained by the fact that participant responses are not included, and details about the broader interactional context from which they have been taken is also not provided. In examining the emergence of face threats in interaction we propose that it is necessary to draw from both the details of the local interaction as well as broader relational histories of the participants.

In the following analysis, we focus on a particular interactional practice that has received only passing attention thus far in studies of interaction, namely, strategic embarrassment. We argue that while such a practice is evaluated by participants as face threatening, it is nevertheless treated as allowable, in the sense of not negatively 
impacting upon their longterm relationship (or evolving face), due to (implicit) appeals to guanxi ('connections') being made between those participants in that interaction.

\section{Analysing strategic embarrassment and face threats}

In order to explore how instances of strategic embarrassment are interactionally achieved coordinate with constituting evaluations of face threats in interactions in business settings in Taiwan, this study focuses on the analysis of authentic interactional data (see also Chen, 1990/91). The primary data set drawn upon in this analysis consists of audiovisual recordings of naturally-occurring interactions involving two different agents from a particular insurance company and their various clients, and between a marketing manager from a department store and the various sponsors of product promotional events in that department store. Forty-four interactions, ranging from twenty seconds to thirty-six minutes long, were recorded. The amount of audiovisual data recorded overall was approximately seven and a half hours. These recordings were gathered in the course of eight weeks of ethnographic observation (held over two separate periods in 2007 and 2009) of workplace interactions involving the two different insurance agents and the marketing manager. The ethnographic observations were recorded in note form by the first author. Participants in the recordings included the insurance agents and their various clients, mediators and persons involved in a car accident where the insurance agent's clients were at fault, as well as the department store manager and various sponsors. The interactions took place in the clients' homes or in their workplaces when the agents went to pass on the renewal forms for insurance, collect insurance fees, or deal with insurance cases, in a local government mediation department, and in the workplaces of the sponsors of promotional events. Most of the interactions were conducted in Taiwanese dialect, with some code-switching into Mandarin Chinese. ${ }^{4}$ A number of follow-up interviews were also conducted with the agents, the marketing manager, and, where possible, with clients. However, it proved difficult in many cases to elicit their perspectives on these interactions as such talk was found to be face-threatening in itself (cf. Bargiela-Chiappini et al, 2007: 149; Pan 2008). ${ }^{5}$ In only a small number of cases, then, did participants readily volunteer their views on the previous interactions that were recorded. These were therefore supplemented with 11 ethnographic interviews conducted with native informants who have an association with insurance company in Taiwan where the ethnographic observations and a number of recordings were made. The informants were approached through the social network of the researchers' main contact in that company (see Chang and Haugh [forthcoming] for detailed analysis of the ethnographic interviews).

In the course of repeated viewings of the recordings of interactions in conjunction with ethnographic observations, a particular practice emerged as salient in the context of business interactions in Taiwan, namely, strategic embarrassment. Essentially, it involves the speaker embarrassing the addressee by bringing up an instance where the speaker's expectations (usually arising from their previous interactions) have not been met by the addressee, something which the addressee is

\footnotetext{
${ }^{4}$ It thus remains an open question whether such interactional practices would arise in business interactions in other Chinese-speaking societies.

${ }^{5}$ This clearly has implications for the analysis of follow-up interview data involving Chinese speakers, as noted by Haugh (2010b: 156-157) in discussing Spencer-Oatey's (2009) study of face threats in a welcoming meeting hosted by a British company for a Chinese delegation.
} 
likely to want to be left unsaid. The speaker attempts to embarrass the addressee into doing what he or she wants by topicalising these unmet expectations, thereby implying a mild reproach or complaint (Drew and Holt, 1988; Drew and Walker, 2009; Schegloff, 2005).

Embarrassment is generally defined, following Goffman’s (1956) seminal work, as a "moment in face-to-face interactions where an individual becomes flustered, momentarily loses self-control, and is unable to comfortably participate in the systematically organised procedures that conversation requires" (Sandlund, 2004: 162). Signs of embarrassment include blushing, blinking, hesitation, absentmindedness, vocal pitch changes, stuttering speech (Goffman, 1956: 265-266), as well as, fidgeting movements, shifting gaze, and ambivalent body postures (Heath, 1988: 153; Lewis, 1993; Sandlund, 2004). According to Goffman (1956), embarrassment arises when "the expressive facts at hand threaten or discredit the assumptions a participant finds he has projected about his identity” (Goffman, 1956: 269), and crucially, that suffering embarrassment in social interaction displays the orientation of participants "to shared norms of conduct" (Goffman, 1956: 268; Sandlund, 2004: 162). Embarrassment thus "emerges in relation to a specific action produced by a coparticipant" (Heath, 1988: 154), either on the part of the speaker or addressee. One may embarrass oneself through one's own behaviour (e.g., loss of body control, social 'gaffes' and so on) (Goffman, 1968: 268-269), or alternatively, one may trigger embarrassment in another co-interactant. The latter has been termed strategic embarrassment in cases where triggering embarrassment in others is built into turn design (Bradford and Petronio, 1998; Gross and Stone, 1964; Sharkey, 1992, 1997):

interactants sometimes use planned communication strategies for triggering embarrassment in a co-interactant...the instigation of embarrassment in others is designed to achieve certain interactional goals. Such goals may be designed to have both positive and negative outcomes, and are thus not always malicious acts to make others uncomfortable. (Sandlund, 2004: 178-179)

A common focus of research in this area has been on teasing as a form of embarrassment elicitor (Sandlund, 2004), and the ways in which it can be exploited to establish or maintain power, express sanctions of another person's behaviour, to discredit someone's presented identity, and to index solidarity (Bradford and Petronio, 1998; Gross and Stone, 1964; Sharkey, 1992, 1997; see also Haugh, 2010a for an overview).

The interactional practice we have identified in our data builds on this work on teasing and embarrassment in identifying another kind of embarrassment elicitor, namely, topicalising unmet expectations. However, we argue here that rather than threatening assumptions a participant has projected about his or her identity (Goffman, 1956: 269) or individual role (Gross and Stone, 1964), topicalising unmet expectations first and foremost threatens the ongoing or evolving relationship between participants. While only one person (or group) is indeed the target of the embarrassment elicitor, unmet expectations only exist through virtue of the ongoing relationship between the participants. The threat to a person from topicalising unmet expectations thus only arises because the speaker is putting on record that the target has apparently not valued their existing relationship. In our analysis, therefore, we treat the threat to their relationships rather than to individuals as primary. ${ }^{6}$

\footnotetext{
${ }^{6}$ This is not to say that participants may not also perceive threats to their person, but this, we argue, is
} 
In the Taiwanese context, the term guanxi is often used to denote the relationship, network or social capital that circulates in reciprocal business relationships. Guanxi, which encompasses both rights and obligations, is employed in establishing harmony and strengthening reciprocal relationships (Pan, 2000: 68-71). The relational roots of these rights and obligations encompassed in guanxi thus differ from those outlined in Spencer-Oatey's (2002, 2005, 2008) Rapport Management Theory where they are located in the social and interactional roles of individuals (see, for instance, Spencer-Oatey 2008: 15-16). An important factor underlying guanxi is gangqing ('emotive quality'), which encompasses either renqing ('human emotion') or jiaoqing ('friendly emotion') (Chang and Holt, 1994; Gao, Ting-Toomey and Gudykunst, 1996; Hwang, 1987; Yang, 1994). Renqing is always associated with the notion of renqing zhai ('human emotion debt'), meaning renqing is something that is expected to be contributed or returned through guanxi, whereas jiaoqing ('friendly emotion') indicates the quality of the friendship or relationship, and is normally under consideration when employing guanxi.

In ethnographic interviews with informants from the insurance industry in Taiwan (Chang and Haugh, forthcoming), the importance of guanxi was repeatedly highlighted, as illustrated in the excerpt from one of the interviews below.

\section{EI-W1: 16:40}

$8 \quad$ I: $\quad$ Na juede tan baoxian huo shi tan shengyi shangmian ni juede women chang jiang guanxi huo shi kao guanxi hen zhongyiao ma? '[Do you think] guanxi/relying on guanxi is very important during insurance business negotiations?'

$9 \quad$ W: Ou, hen zhongyao, erqie shi feichang feichang feichang de zhongyao, er, zhuangye lingyu ou, ta zhi shi ni gongzhuo biyao de dongxi eryi, zhuangye shi ni de biyao, yinwei na shi ni zhuangmen shengcai de qiju ma. Buguo zhe ge guanxi, zhe ge guanxi meiyou de hua, huo zhi ni lien guanxi dou kao bu liao de hua, na jiu buhao yisi, ruguo ni yao zai shehui shang shencun, keneng yao bi bieren duo baifenzhi bashi de nuli. Na jintian ruguo you guanxi de hua, renjia shuo, ruguo qu dao yi ge qienjin xiaojie, keyi shao fendou sanshi nian, yi yang yisi ma. 'Oh, very important, and [it's] very very very important. Hmm, [In] professional area, it is just a necessity of your job. Your profession is the necessity because it is your tool of making money. However, if you do not have any guanxi or you do not know how to rely on guanxi, then I'm sorry. If you live in this society, you may have to put 80 percent more effort than others. If you have guanxi, [it's like] what people say, "if you marry to a lady from a rich family, you can work 30 years less than others.” The meaning is the same.'

In this excerpt the informant responds to a question about the importance of guanxi from the interviewer (turn 8). He emphasises that guanxi is indeed very important in

only consequential in these instances because of their ongoing relationship. It remains an empirical question, we believe, whether evaluations of threats to relationships or to persons should be treated as primary in each particular interaction. There has been work on the role of identity work in business interactions in Hong Kong (Kong, 2001, 2002, 2003), for instance, which indicates that in some cases threats to persons/identities may be more salient. 
business, implying that if one does not have guanxi or does not know how to use them, then one is unlikely to be very successful (turn 9). He goes on invoke a common Taiwanese saying (ruguo qu dao yi ge qienjin xiaojie, keyi shao fendou sanshi nian, 'if you marry to a lady from a rich family, you can work 30 years less than others'), which in this context means that the better quality guanxi one has cultivated, the more likely one will be successful in business. This is not suggest that such relational rights and obligations, and associated emotivity, are in any way unique to Taiwanese (or Chinese more broadly) (Chan, 2008), but rather only to point out that guanxi are salient to the analysis of actions and evaluations (including those of face threats) in business interactions in Taiwan, which furnishes further support for our focus on relationships in this analysis.

Topicalising unmet expectations invokes the obligations that accompany ongoing relationships between participants in business interactions. In doing so, however, a threat to the speaker-hearer's face arises, because in bringing up these unmet expectations, it is implied that the hearer has not valued their existing relationship and, in some cases, their reputations within the context of that relationship. However, we suggest in our analysis that this practice is treated as allowable through participants (implicitly) appealing to their guanxi ('connection') in the course of the interaction. Strategic embarrassment is thus only possible because business people in Taiwan place great value on their relationships. It is also worth noting that topicalising unmet expectations occasions an opportunity for the addressee to fulfil these expectations, and thereby strengthen their relationship and associated reputations. In other words, by meeting these expectations through his or her response, the recipient may arguably occasion evaluations of face support, subsequent to the previously constituting an evaluation of face threat.

The interactional achievement of strategic embarrassment coordinate with constituting evaluations of face threat can be observed in the following incident which took place at the client's (Chen) business when an insurance agent (Lan) went to collect the annual insurance fee for Chen's property. Both participants spoke in Taiwanese for the entire conversation. The key incident involving strategic embarrassment occurs when Lan threatens their relationship as he attempts to persuade Chen to transfer the insurance for one of his cars back to Lan's company. Since Lan and Chen have known each other for more than fifteen years, they have established a long-term relationship based on Chen buying insurance from Lan's company. Having such a long-term relationship does not necessarily imply closeness in the sense of intimacy, but rather a sense of mutual obligation. Lan succeeds in persuading Chen to shift his car insurance case from another company to Lan's company through strategic embarrassment. As both Lan and Chen are demonstrably orienting to the threats to their relationship in this interaction, we suggest that this strategic embarrassment is evaluated as face threatening. However, this face threat is allowable (i.e., relationship-appropriate) because of the way in which Lan appeals to guanxi. $^{7}$

(1) IR-4

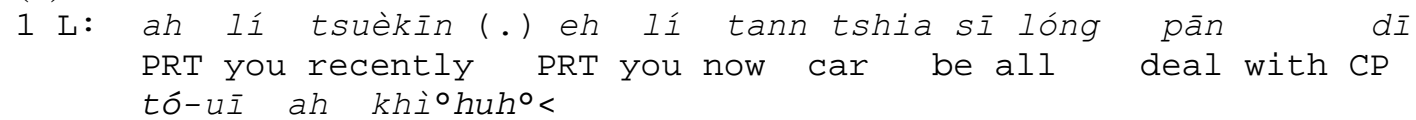

\footnotetext{
${ }^{7}$ The conversations were transcribed according to standard conversation analytic conventions (Jefferson, 2004), and also translated into English. A list of transcription symbols can be found at the end of this paper, along with the symbols used in morphological gloss.
} 
where PRT CP PRT

"Ah where is your car [insurance] being dealt with recently?"

$2 \mathrm{C}$ : tshia? $(0.2)^{\circ}$ tshia $\downarrow(0.1)$ huètshia ${ }^{\circ}$ huè -\#\#guá tse tō >kiau-< car car van van- me this be sedan-

kiau-tshia ooh?=

seden PRT

"Car? car van van this is-, this is van van you mean the sedan?"

3 L: =tshia guá tann guá ah bo puànn tâi ah†((swishing hand))> car I now I PRT N half C PRT

lín bú a tsit-leh kóng bé ho guá 'bé ho guá ${ }^{\circ}=$ your mum PRT once say want give me want give me

"Now I don't have any half of [your] car [insurance]. Your mother once said she wants to give it [insurance case] to me" ((phone rings))

$4 \mathrm{C}:=>a h$ tshia $<$ ((looking away)) e:: guá hit tai huètshia PRT car PRT I that C van

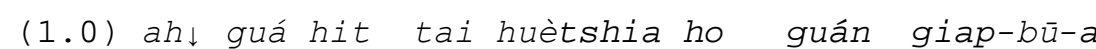
PRT I that $\mathrm{C}$ van give our business agent

pān lah (.) guán giap-bū-a pān lah

handle PRT our business agent handle PRT

"How do I know. Er, that van. Ah, that is being dealt with by my business agent, being dealt with by my business agent."

5 L: lín giap-bū-a kam ū- siánn-mih ū siánn-mih your business agent ${ }^{5}$ could have what have what $>$ hit $-1 \bar{o}-a ?<$

that

"Your business person, What what does [he] have?" (2.๑) ((chair squeaking))

$6 \mathrm{C}:(($ looking into distance $))$ ah:>tiu< tiu: $(($ patting envelope $))=$ PRT that's that's

$7 \mathrm{~L}:=[$ lí] hit tai tang-sî kàu-kî?

"Ah, that's, that's..."

your that $C$ when due

"When is [the insurance of car] due"

$8 \mathrm{C}$ : >guán hit jà< tang-sî̀ kàu-kî?

our that $\mathrm{C}$ when due

"When is [the insurance of our car] due?"

( (chair squeaking))

9 L: ${ }^{\circ}$ kin-nî tsuán toh tńg-lâi ${ }^{\circ}=$

this year shift $\mathrm{CP}$ back $\mathrm{CP}$

"Shift back [the insurance] this year."

$10 \mathrm{C}:=$ hó lah [hó lah]

alright PRT alright PRT

"Alright, alright."

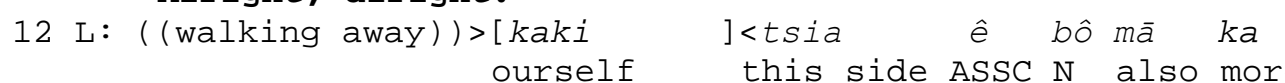

sittsai: :

down-to-earth

13 C: hó lah hó

"It's more reliable to deal with people on your side"

alright PRT alright

"Alright, alright"

$14 \mathrm{~L}:{ }^{\circ}$ heh $a h^{\circ}$

right PRT

"Right ."

$15 \mathrm{C}$ : ' ${ }^{\circ}$ ó [ah॰

alright PRT

"Okay." 


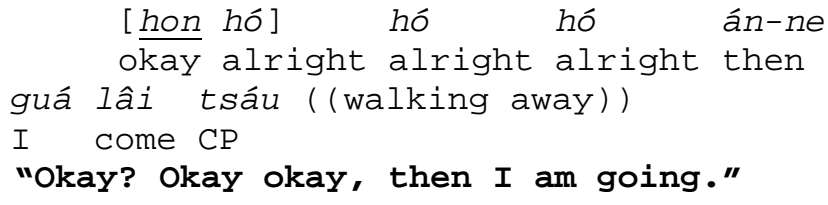

This excerpt begins when Lan brings up the topic of which company Chen insures his car with at present, which foreshadows the subsequent emergence of an implied complaint. In doing so, a sequence where Lan attempts to persuade Chen to shift his car insurance back to Lan's company is initiated (turns 1-16). The sequence begins with the pre-request "where is your car (insurance) being dealt with recently?", which establishes the grounds for making this request in turn 9 (Rue and Zhang, 2008). Lan presupposes through his pre-request that Chen has given the insurance case to someone else instead of Lan, despite their long-term business relationship (guanxi). Chen responds in a hesitant and repetitive manner in turn 2 focusing ostensibly on fixing the reference for which vehicle they are talking about. Lan then goes on to say that he has not been given any car insurance cases by Chen in turn 3, thereby implying a complaint that Chen did not keep his (previous) promise (to shift the insurance case to Lan) (Wu, 2003). Chen indexes an embarrassed (buhaoyisi) stance in answering this question in turn 4 through his pausing and hesitation, and by cutting his line of gaze towards Lan (Heath, 1988: 145-146; Sandlund, 2004: 163; Yang, 2010: 195-198). Then Lan continues on to ask "what Chen's business person has" in turn 5 using the Taiwanese term ' $\bar{u}$ siánn-mih', which implies either that Chen's business person must have some kind of ability or, more likely, a special relationship (guanxi) with Chen. In doing so, Lan implies a second complaint as to why he has not been given the car insurance case by Chen, to which Chen expresses his reluctance to respond in turn 6, through cutting his line of gaze towards Lan and his fidgeting body language, thereby once again indexing embarrassment (Heath, 1988: 145-146; Sandlund, 2004: 163; Yang, 2010: 195-198). In turn 7, Lan returns to the request sequence with another pre-request asking when the insurance is due, to which Chen responds by repeating the question, thereby showing hesistancy and nervousness. Strategic embarrassment is thus interactionally achieved through Lan topicalising his expectation that Chen will insure with Lan's company, and Chen's subsequent display of embarrassment. The fact Chen does not answer Lan's question in turn 7 leads in turn 9 into Lan pursuing a response from Chen (cf. Pomerantz, 1984) by directly asking Chen to shift the insurance back to him. Chen at this point responds with immediate agreement (turn 10). In immediately agreeing, Chen allows Lan to enact authority and power over him, thereby evoking their guanxi ('connection'). Lan subsequently employs the term 'kaki (Taiwanese)' (cf. Mandarin: zijiren) or 'insider' in turn 12 to emphasise the importance of their in-group relationship through an appeal to their guanxi ('connection') again. In turns 15 and 16, then, in response to Lan's imperative request, Lan and Chen reach an agreement that Chen will shift his car insurance back later in the year.

In the course of this sequence, Lan appears to accomplish a particular interactional goal, namely, getting Chen to shift his car insurance back to Lan's company (cf. Spencer-Oatey, 2009). Reaching this goal involves moves that can be evaluated as face-threatening. Drawing from FCT, there are three face interpretings involved in the constitution of evaluations of face threat through the course of this sequence. In bringing up an instance where his expectations in regards to Chen buying car insurance from his company have not been met, and then going on to imply complaints about this (turns 3 and 5), Lan appears to project that Chen will interpret 
their relationship as having a lesser degree of connectedness (projected face). Chen also appears to interpret these two complaints on Lan's part as implying that Lan is dissatisfied with this lower degree of connectedness, as he indexes an embarrassed stance through showing hesitation and reluctance to respond to Lan's line of questioning in turns 4 and 6 (interpreted face). Up until this particular interaction, Lan and Chen have had a long-standing business relationship developed over the course of 17 years, which encompasses mutual obligations they are expected to meet (i.e. Chen has consistently obtained insurance from Lan's company, while Lan has maintained a personal interest in Chen's business). Their degree of connectedness can thus be characterised as having been fairly high (evolving face). In this particular interaction, both participants also understand that Lan's call is a business one, where naturally the aim is for them to make money in conducting their business, as well as to maintain good relations for future business dealings. There is nothing invoked in the current context, therefore, which suggests expectations in regards to their degree of connectedness are different from those they have previously had (contextual face). As Lan and Chen interactionally achieve strategic embarrassment, the proffered shift involves diverging interpretings between their projected/interpreted face and evolving face, as the former involves a lower degree of connection than the latter. On the other hand, there is no difference between their evolving face and contextual face, and thus the situated shift involves no divergence in their understandings of their degree of relational connectedness. As the proffered shift and situated shift in face interpretings are not consistent, Lan's projecting and Chen's interpreting of face are evaluated as threatening. In other words, as the two men interactionally achieve strategic embarrassment in the course of this sequence, both find their relationship or face to be threatened. However, while the interactional achievement of strategic embarrassment is arguably evaluated as face threatening, it does not negatively impact on their longterm relationship (evolving face). This is because Lan appeals to expectations about their relationship that he might reasonably have, namely, their guanxi ('connection'), which thereby enables this face threat to be treated as allowable in that interaction.

Notably, Lan's move to embarrass Chen about the car insurance through topicalising unmet expectations appears to be understood by the participants as occasioning an opportunity for Chen to fulfil these unmet expectations, thereby creating interactional space for Chen to repair this threat to their relationship, which Chen does indeed do through accepting Lan's request. In terms of FCT, the achieving of strategic embarrassment in effect changes Lan and Chen's evolving face in the direction of much reduced connectedness. However, both their contextual face and Lan's projecting that Chen will interpret the embarrassment as an opportunity to fulfil expectations involve relatively higher connectedness, resulting in a situated shift in face interpretings. Chen's acquiescence to Lan's request occasions an interpreting of greater connectedness, thereby leading to a proffered shift in face interpretings. As both the situated shift and the proffered shift involve convergence, the relationship or face is thus supported. In this way, while the strategic embarrassment initiated by Lan through topicalising unmet expectations is arguably face-threatening, it subsequently occasions a response that is evaluated as face-supportive. ${ }^{8}$

\footnotetext{
${ }^{8}$ In a subsequent interaction that follows Chen appears to change his mind about shifting his car insurance back to Lan's company by giving reasons why he chose the other company. However, Lan is eventually successful in gaining this case from Chen (Chang and Haugh, forthcoming). And indeed they have, according to the agent, continued to have an ongoing business relationship in the three years since this interaction was recorded.
} 
This incident thus involves the interactional achievement of strategic embarrassment through complaints implied by Lan in regards to unmet expectations. That this sequence involves the interactional achievement of threats to their face is apparent from the way Chen becomes defensive and embarrassed by the line of questioning from Lan. Those threats to their face also involve Lan explicitly invoking the expectations that follow from their long-term relationship between himself and Chen which has been established over a number of years (i.e., their guanxi). In this way, the face threat is treated as relationship-appropriate and so allowable by Chen and Lan. This relationship is also the basis of evaluations of face support arising from Chen's subsequent agreement to shift the insurance case back to Lan's company. The incident therefore shows the importance of taking relationships into account when analysing face in interactions between Taiwanese, as it is through invoking relationship-bound expectations (guanxi) that Lan is able to enact power with regard to Chen and achieve his interactional goals.

The interactional achievement of strategic embarrassment can also be seen to emerge in another incident involving the same insurance agent going to another client's workplace. Here, the insurance agent, Lan, goes to Chu's factory to hand over a renewal form for annual property insurance. Both participants spoke in a mixture of Taiwanese (represented in italics) and Chinese Mandarin (non-italicised). Through the course of this excerpt Lan and Chu constitute threats to their face. In the conversation preceding this excerpt, Lan has handed over the insurance renewal forms, to which Chu has responded by asking Lan why he did not give him the renewal forms before the expiry date. Lan then explains that the company car insurance will remain active as long as Lan has already renewed Chu's annual insurance. Following this explanation, Lan interrupts Chu and asks him about accident insurance for his employees in order to try to get another insurance case from Chu. In attempting to obtain another insurance case, the interactional achievement of strategic embarrassment arises coordinate with constituting evaluations of face threats.

(2) IR-20

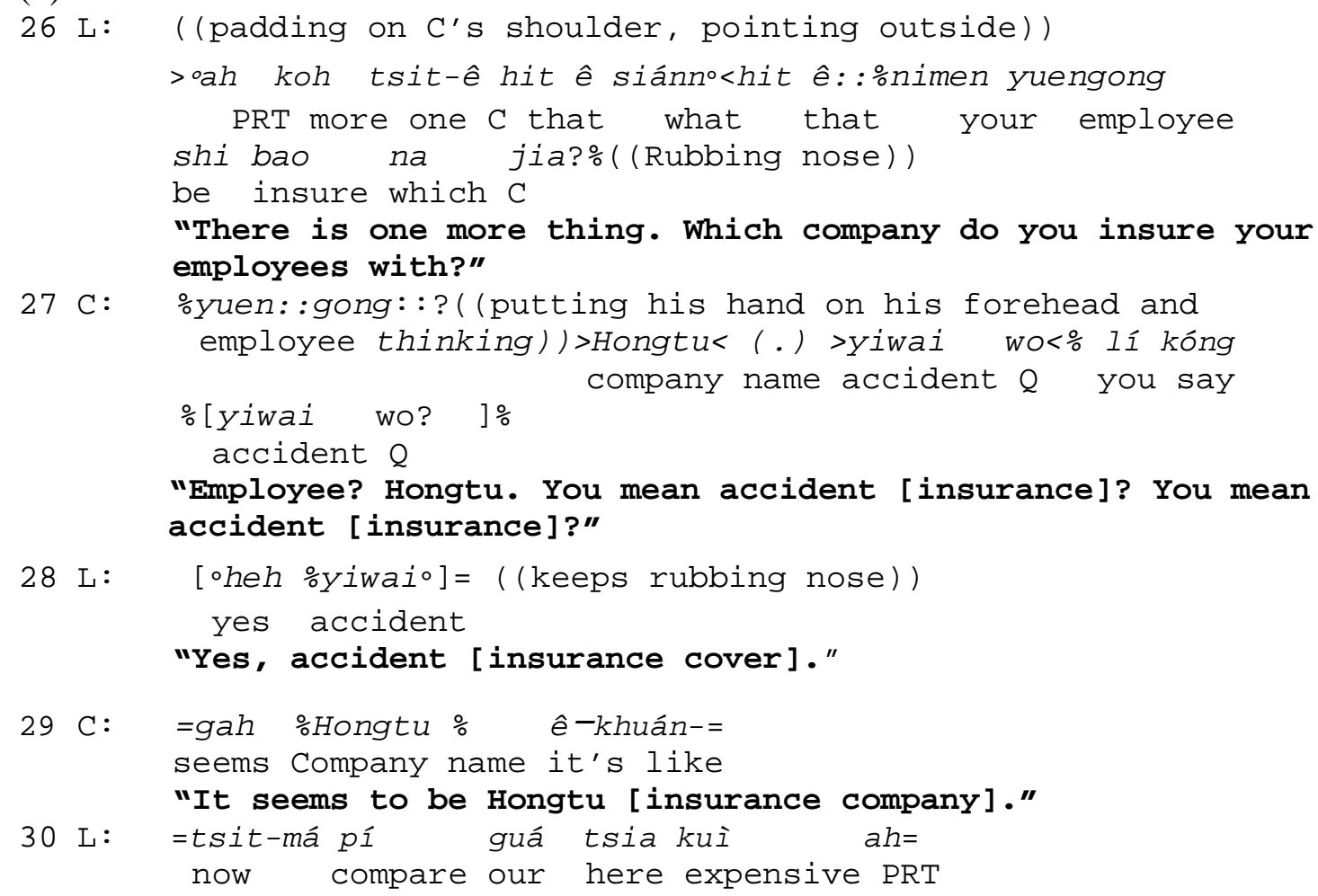




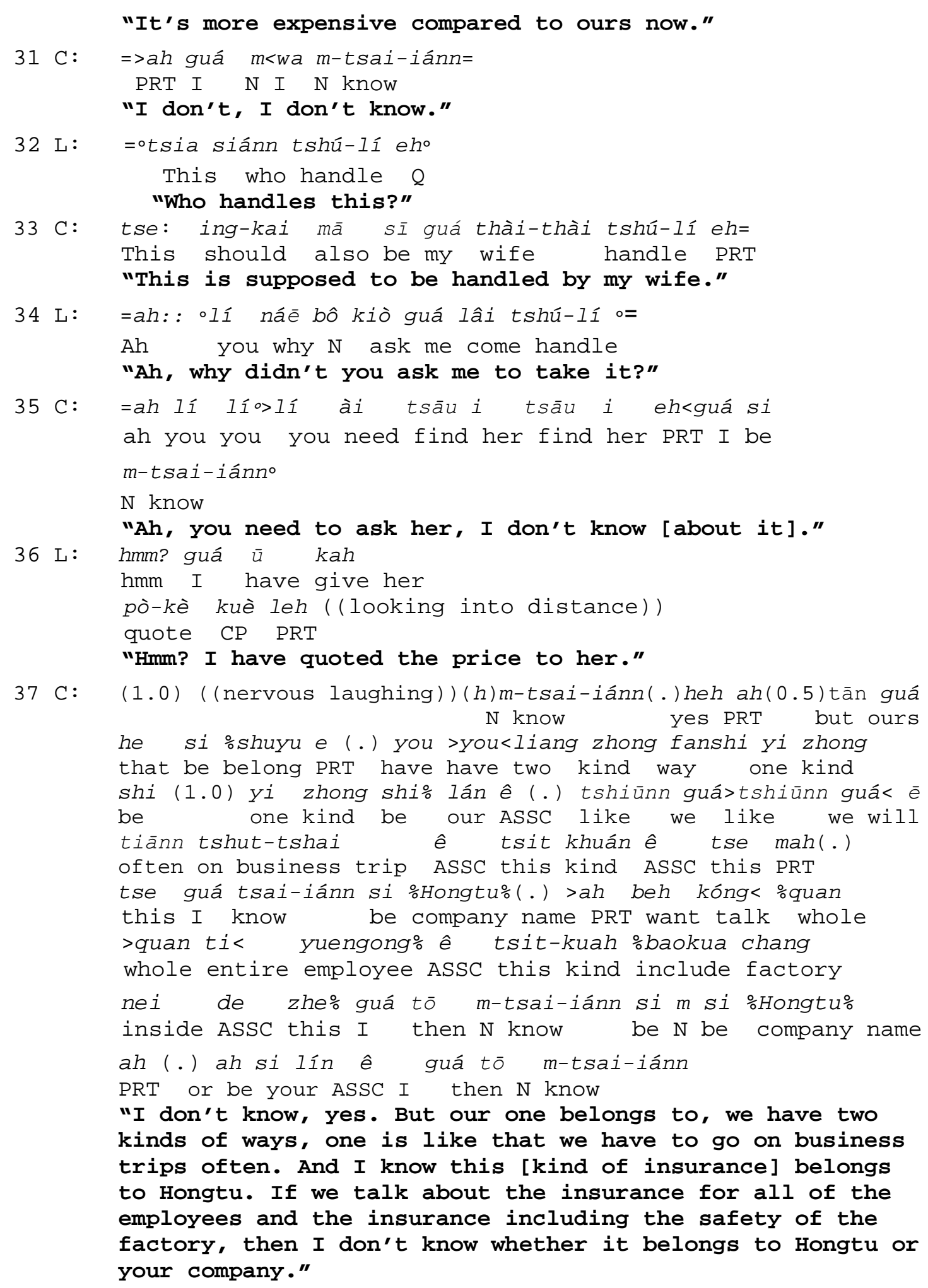

37 C: (1.0) ((nervous laughing))(h)m-tsai-iánn(.)heh ah(0.5)tān guá $\mathrm{N}$ know yes PRT but ours

he si \%shuyu e (.) you >you<liang zhong fanshi yi zhong that be belong PRT have have two kind way one kind shi (1.0) yi zhong shi\% lán ê (.) tshiūnn guá>tshiūnn guá< ē be one kind be our ASSC like we like we will tiānn tshut-tshai $\hat{e}$ tsit khuán ê tse mah(.) often on business trip ASSC this kind ASSC this PRT tse guá tsai-iánn si \%Hongtu\%(.) >ah beh kóng< \%quan this I know be company name PRT want talk whole $>$ quan ti< yuengong\% ê tsit-kuah \%baokua chang whole entire employee ASSC this kind include factory nei de zhe\% guá tō m-tsai-iánn si $m$ si \%Hongtu\% inside ASSC this $\mathrm{I}$ then $\mathrm{N}$ know be $\mathrm{N}$ be company name ah (.) ah si lín ê guá tō m-tsai-iánn PRT or be your ASSC I then N know "I don"t know, yes. But our one belongs to, we have two kinds of ways, one is like that we have to go on business trips often. And $I$ know this [kind of insurance] belongs to Hongtu. If we talk about the insurance for all of the employees and the insurance including the safety of the factory, then I don't know whether it belongs to Hongtu or your company."

At the beginning of this excerpt, Lan interrupts Chu's ongoing speech in the preceding turn and signals that he is going to change to a new topic by patting on Chu's shoulder and pointing to outside (turn 26). Lan then asks "There is one more thing. Which company do you insure your employees with?”, which topicalises a particular insurance case, thereby initiating a request sequence where he attempts to persuade Chu to take accident insurance for his employees with Lan's company. Lan frames his pre-request, however, as tentative as he hedges the question with verbal tokens (hele), 
elongation, softening the speech, and rubbing his nose in a manner that projects hesitancy, and possible embarrassment (Goffman, 1956: 264; Heath, 1988: 153; Sandlund, 2004: 163; Yang, 2010: 206-211). Chu in turn responds to this pre-request by projecting discomfort and possible embarrassment through hesitation, elongation and repetition, as he ostensibly attempts to fix the reference for which type of insurance Lan is referring to (turn 27). Although Chu has already said the name of the other insurance company (Hongtu), he still seeks clarification about which kind of insurance Lan means, indicating that he may be reluctant to inform Lan which company he is insuring his employees with. In his next turn, Lan continues to project nervousness through his continuous nose rubbing and weak tone of voice as he confirms that he means accident insurance for employees (turn 28). However, this utterance does not merely serve as a response to Chu's clarification, but also has an interrogative embedded, namely, inquiring which company Chu has insured his employees with. Chu's subsequent response in turn 29 where he confirms that it is Hongtu, is hedged with tokens (ga...ye kuan, 'it seems like'), thereby positioning himself as uncertain about this. Nevertheless, Lan goes on in turn 30 to comment about the price of the other company, claiming that it is more expensive than his own, thereby implicitly criticising Chu for insuring with the other company. Chu's redundant verbal tokens are evidence of Chu's nervousness and embarrassment about Lan's claim and implied criticism (turn 31). Lan next asks “who handles this?”, seeking to find out who is responsible for this matter in turn 32. Chu responds that his wife is the one who contacts the Hongtu company (turn 33). Lan then directly asks “why didn’t you ask me to take it?” in the following turn. In doing so, Lan presupposes that since he has been managing the company car insurance cases for Chu's factory, he expects he should be the one to be relied on for other insurance cases, thereby invoking their established business relationship. In his subsequent response (turn 35), Chu again denies direct knowledge of the case and shifts the focus to his wife by saying “Ah, you need to ask her, I don’t know [about it]”. Lan implies a complaint about this again in turn 36 in claiming that Chu's wife knows Lan's company offers cheaper accident insurance for employees. Chu then responds with considerable redundancy accompanied by concomitant nervous laughter (Glenn, 2003) after a one second pause, in giving a long explanation to satisfy Lan's pursuit of a response (Pomerantz, 1984). At this point, Lan abandons the request sequence as Chu's wife is not there at the factory so nothing more can be said at that point.

In the course of this sequence, Lan attempts to accomplish a particular interactional goal, namely, getting Chu to shift his employee accident insurance back to Lan's company. However, this time he is not successful, at least not in the shortterm. Lan attempts to persuade Chu through topicalising unmet expecations, thereby interactionally achieving strategic embarrassment. These moves are also evaluated as face-threatening. In showing he expects Chu to buy accident insurance from his company, and then going on to imply complaints about the fact that Chu has bought it from another company, Lan projects an interpreting of Chu's interpreting of their relationship as having a lesser extent of connectedness (projected face). In contrast to the previous incident, however, Lan frames his pre-request (turn 26) and complaints (turns 30, 34 and 36) more tentatively by showing his hesitation or embarrassment to make them. Chen also appears to interpret these implied complaints as Lan expressing dissatisfaction with the lower degree of connectedness arising from these unmet expectations, as he shows hesitation and reluctance to respond to Lan's line of questioning, and indeed tries to shift the responsibility for that decision to his wife rather than himself (interpreted face). Similar to the previous interaction, Lan and Chu 
have developed a business relationship over the course of five years during which Chu has obtained his insurance from Lan's company, while Lan has maintained a personal interest in Chu's business. Their degree of connectedness can be characterised as having been fairly high thus far (evolving face), although Lan's greater degree of tentativeness suggests that his relationship with Chu may not be as close as his relationship with Chen (which is a reflection of the length of time of their business dealings). There is also nothing invoked in the current context to suggest that their expectations in regards to their degree of connectedness are any different from those which they previously had (contextual face). We can see here, then, that the proffered shift in their face involves divergence between their projected/interpreted face and evolving face due to Lan implying a complaint through topicalising unmet expectations, while the situated shift involves no divergence between their evolving face and contextual face. This difference gives rise to an evaluation of the current face interpreting as threatening to their relationship. However, once again, while this action is evaluated as face threatening, it did not negatively impact on their long-term relationship (evolving face). This is because Lan arguably appeals to expectations he might reasonably hold as a consequence of having had a long-standing business relationship through this move, with his appeal to guanxi also being alluded to in follow-up interviews with Lan. These implicit appeals to their guanxi thus enabled this face threat to be received as allowable in that interaction.

In contrast to example (3), however, Lan is here unsuccessful, as Chu ultimately shifts the negotiations about this to his wife. Yet although Chu does not promise Lan to shift the insurance cases to him at the end of the interaction, he states that he will find out more information about the insurance conditions from his wife later, and thereby demonstrates (at least on the surface) concern about Lan's questions. In this way, Chu's response while not necessarily open to evaluation as face supportive, is at the very least not face threatening. Notably, Lan and Chu have also continued to have an ongoing business relationship since the recording was made.

This incident involves constituting threats to Lan and Chu's face. The threats arise from Lan's pursuit of a response through repeated questioning about employee accident insurance in Chu's factory, which appear to be an attempt to obtain a further insurance case for Lan's company. This line of questioning, through which he implies complaints, threatens their face in light of their long-term, established relationship with each other. However, it is apparent from Lan's nervous questioning and concomitant body language in the interaction that he is aware of the potential threats to their face that he is projecting. Yet he nevertheless persists in this line of persuasion, indicating that strategically embarrassing his client and thereby threatening their relationship and face constitutes a recognisable interactional practice in Taiwanese business contexts.

We conclude our analysis of strategic embarrassment and the co-ordinate constitution of evaluations of face threat by briefly introducing an excerpt from an interaction involving yet another insurance agent, who this time was the target of strategic embarrassment. In this case, unmet expectations were topicalised by one of the representatives of two persons that were involved in a car accident where the insurance agent's clients were at fault. The interaction took place in a local government mediation department. In this mediation session, the committee mediator (CM), the committee vice-chair (CVC) who is representing the people who were hurt in the car accident along with another representative, the insurance agent (Ying), and the clients of that agent who caused the accident were all present. At this point in the 
meeting where the excerpt begins, the CVC is trying to get the insurance agent, Ying, to agree to increase the indemnity payment.

(3) Yi-lan mediation committee 100727001

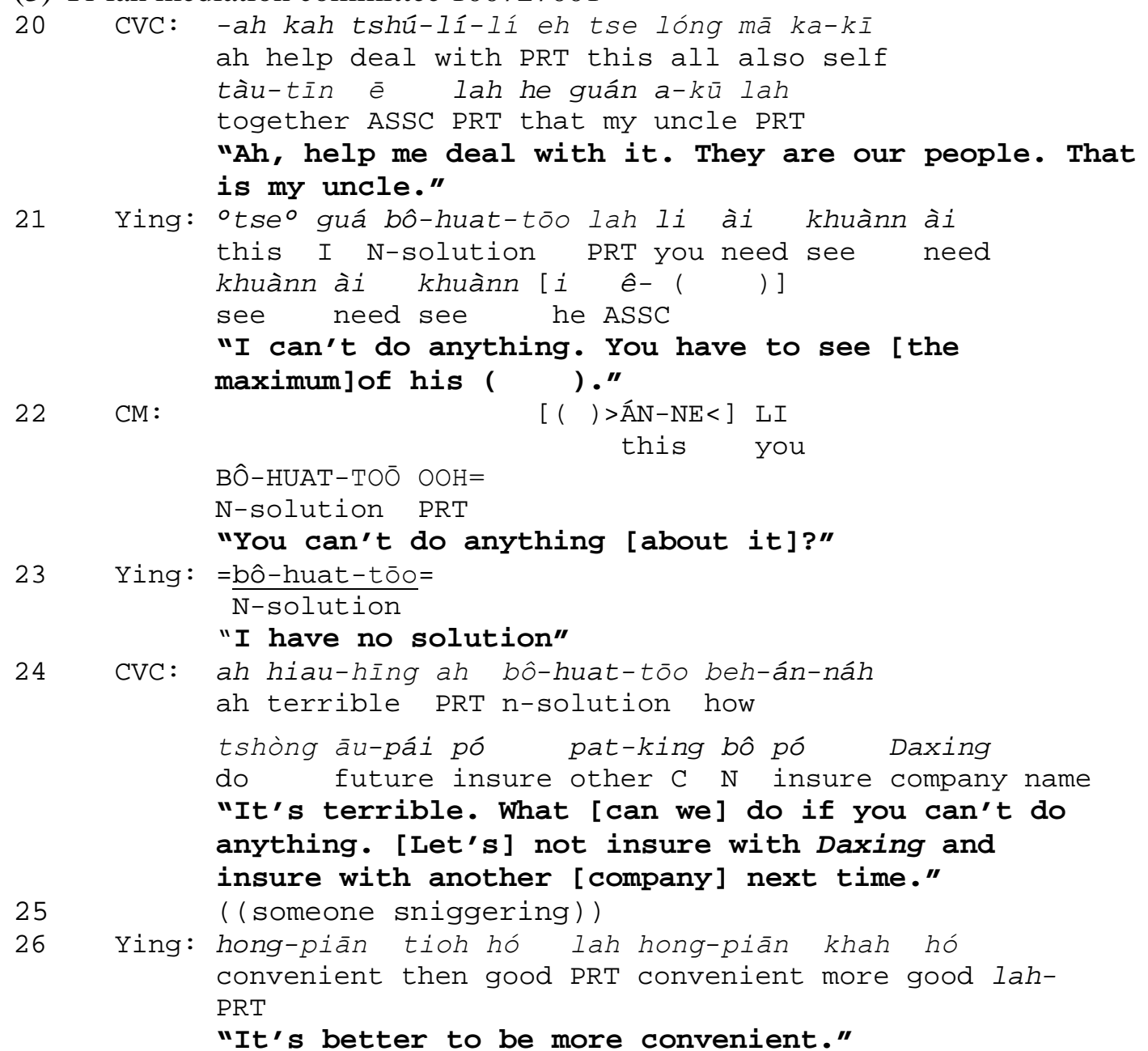

The committee vice-chair explicitly invokes in turn 20 the familial relationship he has with the victims of the car accident, namely, he is the nephew of the victims. As he is also the committee mediator's son, he is also able to implicitly appeal to the long-standing friendship between Ying and the committee mediator. In other words, he is able to ask for special favour due to the presence of an intermediatory (i.e., his father) who mediates the guanxi ('connection') between himself and the insurance agent. Ying responds by claiming he is not able to offer a greater amount of compensation and starts to offer an account for this (turn 21). However, before he finishes this account the committee mediator interrupts in turn 22 with a reformulation of the committee vice-chair's previous explicit request as a question, which only implies a request for greater compensation. However, since this reformulated question has a negative polarity (i.e., 'can't do anything'), disconfirmation is the (structurally) preferred response (Heritage and Raymond forthcoming; Raymond 2003; Stivers and Enfield 2010), which Ying indeed provides in turn 23. In this way, it is confirmed that Ying's insurance company is not able to increase the amount of compensation. The committee vice-chair immediately responds in turn 24 with a strong negative assessment (ah hiau-hing, 'it's terrible') in relation to his uncle having to pay the costs of medical treatment himself, and then implies that other insurance companies 
would offer better indemnity payments. In this way, he invokes an expectation that Ying should be able to offer a better indemnity payment. In topicalising this unmet expectation, then, the committee vice-chair is occasioning strategic embarrassment for Ying. The agent's subsequent response in turn 26 is disaligning, as it has no direct relevance to the committee vice-chair's previous turn, and thus arguably displays embarrassment on his part. The laughter of others (turn 25) also indicates that this topicalising of unmet expectations is indeed embarrassing for Ying.

This strategic embarrassment is interactionally achieved coordinate with the constitution of evaluations of a number of face threats in a similar manner to the examples previously discussed. We will concentrate in this analysis, however, on what is arguably the primary face threat arising in this part of the meeting, namely, the threat to Ying's relationship with his clients as a competent agent representing an insurance company that offers good services. ${ }^{9}$ In the course of the above sequence, the committee vice-chair attempts to negotiate a greater amount of compensation for the victims of the car accident he is representing through topicalising unmet expectations, namely, that they would expect other insurance companies would provide a higher level of compensation. In interactionally achieving a negative assessment of Ying and his company in front of all those present at the mediation meeting, the committee vice-chair projects that Ying lacks the ability to offer good services as an insurance agent to others (and so impugns the reputation of his company more broadly). In this way, he projects an interpreting of Ying's relationship with his actual clients as having a lesser extent of connectedness (projected face). Ying has a long-standing relationship with his existing clients, and thus his degree of connectedness can be characterised as having been fairly high thus far (evolving face). There is also nothing invoked in the current context to suggest that their expectations in regards to their degree of connectedness has altered in any way. The proffered shift in face thus involves a divergence between the projected/interpreted face and evolving face due to the committee vice-chair topicalising unmet expectations in regards to compensation, while there is no situated shift in face, since there is no divergence between their evolving face and contextual face. This difference between the proffered shift and situated shift gives rise to an evaluation of the current face interpreting as threatening to their relationship. Notably, Ying was not able to offer greater compensation during this meeting, and so in the end the case was passed on to another agent in his company.

Finally, we would like to conclude with further evidence that strategic embarrassment is not only a recognisable but also a recurrent practice in business interactions in Taiwan. In a follow-up interview with this insurance agent, Ying, he commented specifically on the actions of the committee vice-chair.

\section{EI-Y1: 1:50}

1 Ying: Na tongchang tamen de jiangfa le, jiu xianba baoxian gongsi daya, "a baoxian gongsi henzao la", "baoxian gongsi hen chajin la”, "hen ying la, peide buhao la", a buran jiushishuo, "xiaci buyao bao tamen la".

'Then what they normally do, they will firstly suppress the insurance company on the basis of [his] position, saying "the insurance is terrible”, "the insurance company is disappointing”, "very unyielding”,

\footnotetext{
${ }^{9}$ Other threats to face include evaluations of the threats to Ying's long-standing friendship with the committee mediator, as well as his potential relationship with possible future clients present at the meeting, although we do not have sufficient space here to discuss these in further detail.
} 
"bad indemnity”. Otherwise, they say, “don’t insure with them next time".'

$2 \quad$ I: $\quad$ Suoyi zheshi hen tongchang de qingkuang lo?

'So is this situation very common then?'

3 Ying: Zheshi hen tongchang de qingkuang, women shi tongchang

buhui zuo suowei de bianbo. Yinwei jiang zhe dongxi shi meiyouyong de ma.

'This is a very common situation, and we don't normally do the socalled refutation because it's useless [to do so].'

In turn 1, Ying generalises about the committee vice-chair's previous negative assessments and topicalising of unmet expectations, which we have characterised here as strategic embarrassment. He claims that this something that people bringing indemnity cases against insurance agents "normally" do. The interviewer then asks whether such a practice is common in turn 2, to which Ying responds in turn 3 that it is indeed common, and something which it is difficult for them to avoid. While follow-up interviews with participants were difficult to accomplish since questioning participants about face-sensitive incidents is face-threatening in itself as previously noted, these comments were volunteered by Ying to the first author in a discussion that followed the mediation meeting. They indicate his view that while he does not necessarily like this practice of strategic embarrassment, it is something which is indeed commonly encountered in business interactions.

\section{Conclusion}

The interactional practice that has been examined here, namely, strategic embarrassment, and its relationship with face, is complex. It thus requires a relatively complex theory of face in which to frame an analysis of it. In particular, a theory of face which takes into account not only the interactional achievement of actions in a local context, but also the ongoing relationships of the participants, as well as particular aspects of the context which can be invoked by participants, is necessary in order to more fully explicate this interactional practice. It has also been argued that the threats examined here are directed at the relationships between the participants first and foremost. While implications for the interpretings of their persons are likely to have also arisen during the course of these interactions, these interpretings of their persons are only relevant because of the ongoing interactional achievement of their relationships. Without relationships, whether they be close and intimate or only temporary, one's projected claims in relation to one's self-image are largely irrelevant. For this reason, the analysis here has focused primarily on the participants' interpretings of their relationships, here conceptualised as face, consistent with the reconceptualisation of face as relational in Face Constituting Theory. This is not to say that an examination of participant interpretings of personal attributes is not important - and indeed in an emic-based analysis of face in Chinese is likely to dominate at times (see Chang and Haugh, forthcoming) - but rather to suggest that the importance of relationships in interpersonal interactions has been relatively neglected in analyses of face threats thus far.

It has also been suggested in this paper that face threats have been relatively under-theorised in politeness and impoliteness research. Moreover, the focus of researchers has been primarily on types of face-work that are identified through the largely pre-theoretical notions of maintaining, saving, giving and losing face inherited 
from Chinese collocations. This has led to the relative neglect of other kinds of interactional practices. While the recent emergence of impoliteness research has led to a focus on face attack and aggravation, it has also inadvertently sidelined practices that can be evaluated as face-threatening yet are not interpreted as impolite. In the course of this paper we have examined one type of practice that is open to evaluation as face-threatening, yet appears difficult to characterise as either polite or impolite, namely, strategic embarrassment. This analysis thus furnishes further support for the view that we need to move beyond our current focus on politeness and impoliteness to a broader appreciation of the range of interactional practices involved in interpersonal interaction (Arundale 2006, 2010; Locher and Watts 2005; Sifianou 2010, 2011; Watts 2003, 2010). While a number of frameworks which suggest this kind of broader focus have been proposed, many have remained tied to Goffman's pre-theoretical conceptualisation of face threats, and so are arguably constrained by this in their capacity to accommodate this broader range of interactional practices in their analyses of face.

\section{Transcription symbols}

$\begin{array}{ll}(.) & \text { micro-pause } \\ (0.2) & \text { timed pause } \\ (\text { ) } & \text { uncertainty about transcription } \\ - & \text { cut-off of prior sound in a word } \\ \text {.hhh } & \text { Hearable aspiration or laugh particles } \\ \text { CAPITALS } & \text { higher pitch volume } \\ \circ & \text { markedly soft speech } \\ \text { underlining } & \text { stressed word or part of word } \\ \uparrow \downarrow & \text { marked rises or falls in pitch } \\ {[]} & \text { overlapping talk } \\ = & \text { talk 'latched' onto previous speaker's talk } \\ : & \text { stretching of sound } \\ ? & \text { rising intonation } \\ (()) & \text { transcriber's description of non-verbal activity } \\ >< & \text { rushed or compressed talk } \\ \% & \text { code-switch (between Taiwanese and Mandarin Chinese) }\end{array}$

\section{Symbols used in morphological gloss}

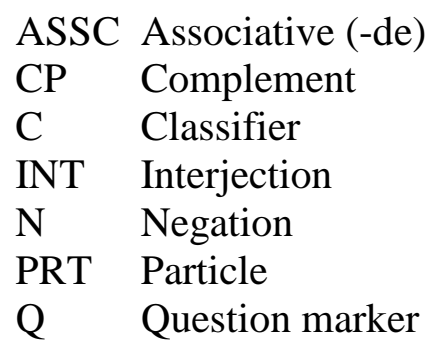

\section{References}

Arundale, Robert, 1999. An alternative model and ideology of communication for an alternative to politeness theory. Pragmatics 9, 119-154. 
Arundale, Robert, 2006. Face as relational and interactional: a communication framework for research on face, facework, and politeness. Journal of Politeness Research 2, 193-216.

Arundale, Robert. 2009. Face as emergent in interpersonal communication: an alternative to Goffman. In: Bargiela-Chiappini, Francesca, Haugh, Michael (Eds.), Face, Communication and Social Interaction. London: Equinox, pp. 33-54.

Arundale, Robert, 2010. Constituting face in conversation: face, facework and interactional achievement. Journal of Pragmatics 42, 2078-2105

Bargiela-Chiappini, Francesca, 2003. Face and politeness: new (insights) for (old) concepts. Journal of Pragmatics 35, 1453-1469.

Bargiela-Chiappini, Francesca, Chakorn, Ora-Ong, Chew, Grace Chye Lay, Jung, Yeonkwon, Kong, Kenneth C., Nair-Venugopal, Shanta, Tanaka, Hiromasa, 2007. Eastern voices: enriching research on communication in business: a forum. Discourse and Communication 1, 131-152.

Bousfield, Derek. 2008. Impoliteness in Interaction. John Benjamins, Amsterdam.

Bousfield, Derek, Culpeper, Jonathan. 2008. Special Issue on "Impoliteness: Eclecticism and diaspora”. Journal of Politeness Research 4, 161-337.

Bousfield, Derek, Locher, Miriam (Eds.), 2008. Impoliteness in Language. Mouton de Gruyter, Berlin.

Bousfield, Derek, Haugh, Michael, 2009. Jocular face-threatening amongst Australian and British speakers of English. Paper presented at the 11th International Pragmatics Association Conference, Melbourne, Australia.

Bradford, Lisa, Petronio, Sandra, 1998. Strategic embarrassment: the culprit of emotion. In: Andersen, Peter, Guerrero, Laura (Eds.), Handbook of Communication and Emotion. San Diego: Academic Press, pp. 99-121.

Brown, Penelope, Levinson, Stephen. 1978. Universals in language usage: politeness phenomena. In: Goody, Esther (Ed.), Questions and Politeness. Cambridge University Press, Cambridge, pp. 56-311.

Brown, Penelope, Levinson, Stephen, 1987. Politeness. Some Universals in Language Usage. Cambridge University Press, Cambridge.

Chan, Ben, 2008. Demystifying Chinese guanxi networks. Business Information Review 25, 183-189.

Chang, Wei-Lin Melody, Haugh, Michael, Forthcoming. Face in Taiwanese business interactions: from emic concepts to emic practices. In: Pan, Yuling, Kádár, Dániel (Eds.), Chinese Discourse and Interaction: Theory and Practice. Equinox, London.

Chang, Hui-Ching, Holt, Richard, 1994. A Chinese perspective on face as interrelation concern. In: Ting-Toomey, Stella (Ed.), The Challenge of Facework. Albany, New York: State University of New York Press, pp. 95-132.

Chen, Victoria, 1990/1991. Mien tze at the Chinese dinner table: A study of the interactional accomplishment of face. Research on Language and Social Interaction 24, 109-140.

Culpeper, Jonathan, 1996. Towards an anatomy of impoliteness. Journal of Pragmatics 25, 349-367.

Culpeper, Jonathan, 2005. Impoliteness and entertainment in the television quiz show: the weakest link. Journal of Politeness Research 1, 35-72.

Culpeper, Jonathan, 2011. Impoliteness. Using Language to Cause Offence. Cambridge University Press, Cambridge. 
Daly, Nicola, Holmes, Janet, Newton, Jonathan, Stubbe, Maria, 2004. Expletives as solidarity signals in FTAs on the factory floor. Journal of Pragmatics 36, 945964.

Drew, Paul, Holt, Elizabeth, 1988. Complainable matters: the use of idiomatic expressions in making complaints. Social Problems 35, 398-417.

Drew, Paul, Walker, Traci, 2009. Going too far: Complaining, escalating and disaffiliation. Journal of Pragmatics 41, 2400-2414.

Ebert, Larry A, Floyd, Kory, 2004. Affectionate expressions as face-threatening acts: receiver assessments. Communication Studies 55, 254-270.

Fraser, Bruce, 1990. Perspectives on politeness. Journal of Pragmatics 14, 219-236.

Fukushima, Saeko, 2000. Requests and Culture: Politeness in British English and Japanese. New York: Peter Lang.

Gao, Ge, Ting-Toomey, Stella, Gudykunst, William, 1996. Chinese Communication Processes. In: Bond, Michael B (Ed.), Chinese Psychology. New York: Oxford University Press, pp. 280-293.

Glenn, Phillip, 2003. Laughter in Interaction. Cambridge University Press, Cambridge.

Goffman, Erving, 1955. On face-work: an analysis of ritual elements in social interaction. Psychiatry: Journal for the Study of Interpersonal Processes 18, 213-231.

Goffman, Erving, 1956. Embarrassment and social organization. American Journal of Sociology 62, 264-271.

Goffman, Erving, 1967. Interaction Ritual. Essays on Face-to-face Behavior. Pantheon Books, New York.

Gross, Edward, Stone, Gregory, 1964. Embarrassment and the analysis of role requirements. American Journal of Sociology 69, 1-15.

Harris, Sandra, 2001. Being politically impolite: extending politeness theory to adversarial political discourse. Discourse and Society 12, 451-472.

Haugh, Michael. 2005. What does 'face' mean to the Japanese? Understanding the import of 'face' in Japanese business interaction. In: Bargiela-Chiappini, Francesca, Gotti, Maurizio (Eds.), Asian Business Discourse. Peter Lang, Berlin, pp. 211-239.

Haugh, Michael, 2007. Emic conceptualisations of (im)politeness and face in Japanese: implications for the discursive negotiation of second language learner identities. Journal of Pragmatics 39, 657-680.

Haugh, Michael, 2009. Face and interaction. In: Bargiela-Chiappini, Francesca, Haugh, Michale (Eds.), Face, Communication and Social Interaction. Equinox, London, pp. 1-30.

Haugh, Michael, 2010a. Jocular mockery, (dis)affiliation, and face. Journal of Pragmatics 42, 2106-2119.

Haugh, Michael, 2010b. Intercultural im/politeness and the micro-macro issue. In: Trosborg, Anna (Ed.), Pragmatics across Languages and Cultures. Berlin: Mouton de Gruyter, pp. 139-166.

Haugh, Michael, Bargiela-Chiappini, Francesca, 2010. Face in interaction. Journal of Pragmatics 42, 2073-2077.

Heath, Christian, 1988. Embarrassment and interactional organization. In: Drew, Paul, Wootton, Andrew (Eds.), Erving Goffman: Exploring the Interaction Order. Cambridge: Polity Press, pp. 136-160.

Heinemann, Trine, Traverso, Véronique, 2009. Complaining in interaction. Journal of Pragmatics 41, 2381-2384. 
Heritage, John, Raymond, Geoffrey, forthcoming. Navigating epistemic landscapes: acquiescence, agency and resistance in responses to polar questions. In: de Ruiter, J. P. (Ed.), Questions: Formal, Functional and Interactional Perspectives. Cambridge University Press, Cambridge.

Ho, David Yau-Fai, 1976. On the concept of face. American Journal of Sociology 81, 867-884.

Hu, Xianjin, 1944. The Chinese concept of face. American Anthropologist 46, 45-64.

Hwang, Kwang-Kuo, 1987. Face and favour: the Chinese power game. American Journal of Sociology 92, 944-974.

Ide, Sachiko, 1989. Formal forms and discernment: two neglected aspects of universals of linguistic politeness. Multilingua 8, 223-248.

Jefferson, Gail, 2004. Glossary of transcript symbols with an introduction. In: Lerner, Gene (Ed.), Conversation Analysis: Studies from the First Generation. John Benjamins, Amsterdam, pp. 13-23.

Kienpointer, Manfred, 1997. Varieties of rudeness. Types and functions of impolite utterances. Functions of Language 4, 251-287.

Kienpointer, Manfred, 2008. Impoliteness and emotional arguments. Journal of Politeness Research 4, 243-265.

Kong, Kenneth C. 2001. Marketing of belief: intertextual construction of network marketers' identities. Discourse and Society 12, 473-503.

Kong, Kenneth C. 2002. Managing the ambiguous and conflicting identities of 'upline' and 'downline' in a network marketing firm. Discourse Studies 4, 49-74.

Kong, Kenneth C. 2003. “Are you my friend?”: Negotiating friendship in conversations between network marketers and their prospects. Language in Society 32, 487-522.

Leech, Geoffrey, 1983. Principles of Pragmatics. Longman, London.

Lewis, Michael, 1993. Self-conscious emotions: embarrassment, pride, shame, and guilt. In Lewis, Michael, Haviland, Jeannette (Eds.), Handbook of Emotions. New York: The Guilford Press, pp. 563-573

Limberg, Holger, 2009. Impoliteness and threat responses. Journal of Pragmatics 41, 1376-1394.

Locher, Miriam, 2004. Power and Politeness in Action. Disagreements in Oral Communication. Mouton de Gruyter, Berlin.

Locher, Miriam, 2006. Polite behaviour within relational work: the discursive approach to politeness. Multilingua 25, 249-267.

Locher, Miriam, Bousfield, Derek, 2008. Introduction: Impoliteness and power in language. In: Locher, Miriam, Bousfield, Derek (Eds.), Impoliteness in Language. Mouton de Gruyter, Berlin, pp. 1-13.

Locher, Miriam, Watts, Richard, 2005. Politeness theory and relational work. Journal of Politeness Research 1, 9-34.

Mao, LuMing, 1994. Beyond politeness theory: 'face' revisited and renewed. Journal of Pragmatics 21, 451-486.

Matsumoto, Yoshiko, 1988. Reexamination of the universality of face: politeness phenomena in Japanese. Journal of Pragmatics 12, 403-426.

Mills, Sara, 2005. Gender and impoliteness. Journal of Politeness Research 1, 263280.

Nwoye, Onuigbo, 1992. Linguistic politeness and socio-cultural variations of the notion of face. Journal of Pragmatics 18, 309-328.

O'Driscoll, Jim, 2007. What's in an FTA? Reflections on a chance meeting with Claudine. Journal of Politeness Research 3, 243-268. 
O’Driscoll, Jim, 2009. Erving Goffman. In: D’hondt, Sigurd, Ostman, Jan-Ola, Verschueren, Jef (Eds.), The Pragmatics of Interaction. John Benjamins, Amsterdam, pp. 79-95.

O'Driscoll, Jim, 2011. Some issues with the concept of face: when, what, how and how much? In: Bargiela-Chiappini, Francesca, Kádár, Dániel (Eds.), Politeness across Cultures. Basingstoke: Palgrave Macmillan, pp. 17-41.

Pan, Yuling, 2000. Politeness in Chinese Face-to-face Interaction. Stanford, CA: Ablex.

Pan, Yuling, 2008. Cross-cultural communication norms and survey interviews. In: Sun, Hao, Kádár, Dániel (Eds.) It’s the Dragon’s Turn. Chinese Institutional Discourses. Berne: Peter Lang, pp. 17-76.

Pérez de Ayala, Soledad, 2001. FTAs and Erskine May: Conflicting needs? politeness in question time. Journal of Pragmatics 33, 143-169.

Pomerantz, Anita, 1984. Pursuing a response. In: Atkinson, Maxwell, Heritage, John (Eds.), Structures in Social Action. Cambridge: Cambridge University Press, pp. 152-163.

Raymond, Geoffrey, 2003. Grammar and social organization: yes/no interrogatives and the structure of responding. American Sociological Review 68, 939-967.

Rue, Yong-Ju, Zhang, Grace Qiao, 2008. Request Strategies. A Comparative Study in Mandarin Chinese and Korean. John Benjamins, Amsterdam.

Schegloff, Emanuel, 2005. On complainability. Social Problems 52, 449-476.

Sharkey, William, 1992. Uses and responses to intentional embarrassment. Communication Studies 43, 257-275.

Sharkey, William, 1997. "Why would anyone want to intentionally embarrass me?" In: Kowalski, Robin (Ed.), Aversive Interpersonal Behaviours. New York: Plenum, NY, pp. 57-90.

Sifianou, Maria, 2010. Linguistic politeness: laying the foundations. In: Locher, Miriam, Graham, Sage (Eds.), Interpersonal Pragmatics. Berlin: Mouton de Gruyter, pp. 17-41.

Sifianou, Maria, 2011. On the concept of face and politeness. In: Bargiela-Chiappini, Francesca, Kádár, Dániel (Eds.), Politeness across Cultures. Basingstoke: Palgrave Macmillan, pp. 42-58.

Spencer-Oatey, Helen, 1993. Conceptions of social relations and pragmatics research. Journal of Pragmatics 20, 27-47.

Spencer-Oatey, Helen, 1996. Reconsidering power and distance. Journal of Pragmatics 26, 1-24.

Spencer-Oatey, Helen, 2000. Rapport management: a framework for analysis. In: Spencer-Oatey, Helen (Ed.), Culturally Speaking. Managing Rapport through Talk across Cultures. Continuum, London, pp. 11-46.

Spencer-Oatey, Helen, 2002. Managing rapport in talk: using rapport sensitive incidents to explore the motivational concerns underlying the management of relations. Journal of Pragmatics 34, 529-545.

Spencer-Oatey, Helen, 2005. (Im)Politeness, face and perceptions of rapport: unpackaging their bases and interrelationships. Journal of Politeness Research 1, 95-120.

Spencer-Oatey, Helen, 2008. Face, (im)politeness and rapport. In: Spencer-Oatey, Helen (Ed.), Culturally Speaking ( $2^{\text {nd }}$ edn). Continuum, London, pp. 11-47.

Spencer-Oatey, Helen, 2009. Face, identity and interactional goals. In: BargielaChiappini, Francesca, Haugh, Michael (Eds.), Face, Communication and Social Interaction. London: Equinox, pp. 137-154. 
Stewart, Miranda, 2008. Protecting speaker's face in impolite exchanges: the negotiation of face-wants in workplace interaction. Journal of Politeness Research 4, 31-54.

Stivers, Tanya, Enfield N. J., 2010. A coding scheme for question-response sequences in conversation. Journal of Pragmatics 42, 2620-2626.

Su, Lily I-wen, Huang, Shu-ping, 2002. Harmonious face threatening acts and politeness: a special consideration. National Taiwan Working Papers in Linguistics 5, 175-202.

Tracy, Karen, 2008. "Reasonable hostility”: situation-appropriate face-attack. Journal of Politeness Research 4, 169-191.

Turner, Ken, 1996. The principal principles of pragmatic inference: politeness. Language Teaching 29, 1-13.

Turner, Ken, 2003. $\mathrm{W}_{\mathrm{x}}=\mathrm{D}(\mathrm{S}, \mathrm{H})+\mathrm{P}(\mathrm{H}, \mathrm{S})+\mathrm{R}_{\mathrm{x}}$ (notes towards an investigation). Revue de Sémantique et Pragmatique 13, 47-67.

Watts, Richard, 1989. Relevance and relational work: linguistic politeness as politic behaviour. Multilingua 8, 131-166.

Watts, Richard, 2003. Politeness. Cambridge: Cambridge University Press.

Watts, Richard, 2005. Linguistic politeness research: Quo vadis? In: Watts, Richard Ide, Sachiko, Ehlich, Konrad (Eds.), Politeness in Language. Studies in its History, Theory and Practice ( $2^{\text {nd }}$ edn). Mouton de Gruyter, Berlin, pp. xixlvii.

Watts, R. J. (2010). Linguistic politeness theory and its aftermath: recent research trails. In: Locher, Miriam, Graham, Sage (Eds.), Interpersonal Pragmatics. Berlin: Mouton de Gruyter, pp. 43-70.

Wu, Ruey-Jiuan, 2003. Stance in Talk: A Conversation Analysis of Mandarin Final Particles. John Benjamins, Amsterdam.

Yang, Mayfair Mei-hui, 1994. Gifts, Favours and Banquets: The Art of Social Relationships in China. New York: Cornell University Press.

Yang, Ping, 2010. Managing miànzi in Mandarin Chinese talk-in-interaction: a nonverbal perspective. Semiotica 181, 179-223. 